B.Y. Ong MD FRCPC, R. Greengrass MD FRCPC, D. Bose MD PH D, G. Gregory MD, R.J. Palahniuk MD FRCPC

\title{
Acidemia impairs autoregulation of cerebral blood flow in newborn lambs
}

Cerebral blood flow (CBF) and autoregulation of cerebral blood flow were assessed in newborn lambs before and after inducing metabolic acidemia. CBF was measured by xenon washout and autoregulation by the change in CBF after increasing mean arterial pressure (MAP) 30 per cent with 0.02 per cent phenylephrine hydrochloride. After surgical preparation, stabilization. and demonstration of the presence of autoregulation, six lambs received $10 \mathrm{mg} \cdot \mathrm{kg}^{-1}$ of lactic acid intravenously over 30 minutes. Arterial $\mathrm{pH}$ decreased from $7.35 \pm 0.01$ (mean \pm SEM) during the control period to $6.96 \pm 0.02$ $(p<0.01)$ at the end of the lactic acid infusion. Arterial blood gases, MAP's, and heart rates did not change. Prior to lactic acid infusion, $C B F$ before and after raising $M A P$ were $53 \pm 3 \mathrm{mll} / 100 \mathrm{~g} / \mathrm{min}$ and $56 \pm 4 \mathrm{ml} / 100 \mathrm{~g} / \mathrm{min}$ respectively. After lactic acid infusion, $C B F$ increased from $54 \pm 2 \mathrm{ml} / 100 \mathrm{~g} / \mathrm{min}$ to $62 \pm 3 \mathrm{ml} / 100 \mathrm{~g} / \mathrm{min}(p<$ 0.05 ) following phenylephrine induced rise in MAP. Five control lambs showed no significant change in any of these variables, including $C B F$, over the same time periods. These data indicate that metabolic acidosis per se does not alter $C B F$, but that metabolic acidosis impairs cerebral vascular autoregulation in hyperoxic lambs. Similar changes in human neonates might result in intracranial haemorrhage.

Key words

BRAIN: cerebral autoregulation, cerebrovascular circulation; ACID-BASE EQUILIBRIUM: acidosis.

From the Departments of Anesthesia, Internal Medicine and Pharmacology, University of Manitoba, Winnipeg, and the Department of Anesthesia, University of California, San Francisco, California.

Supported by grants from St. Boniface General Hospital Research Foundation Inc., Health Sciences Centre Research Foundation, Winnipeg Foundation and Medical Research Council of Canada.

Address correspondence to: Dr. B.Y. Ong, Department of Anesthesia, Health Sciences Centre, 700 Wiliam Avenue, Winnipeg, Manitoba, Canada, R3E 0Z3.
Normoxic newborn lambs with normal $\mathrm{pH}$ maintain their cerebral blood flow constant despite fluctuations in mean arterial blood pressure between 45 and $90 \mathrm{mmHg}{ }^{1}$ The maintenance of relatively stable perfusion to an organ in the face of arterial blood pressure alterations is termed autoregulation. Whether acidemia per se affects autoregulation of cerebral blood flow in neonates is still unclear.

The results of previous studies in neonatal animals give conflicting results. ${ }^{2,3}$ Mann et al. ${ }^{2}$ reported no change in carotid blood flow when lactic acid was infused into foetal lambs. Bucciarelli and Eitzman ${ }^{3}$ reported a linearly related change in cerebral blood flow with hydrogen ion concentration in neonatal goats. Since disturbances in cerebral circulation have been implicated as aetiologic factors in perinatal hypoxic-ischaemic and/or haemorrhagic brain injuries, ${ }^{4,5}$ we investigated the effects of lactic acidemia on cerebral blood flow and autoregulation in newborn lambs.

\section{Methods}

Eleven 1-3-day-old lambs were anaesthetised with 70 per cent nitrous oxide- 30 per cent oxygen and paralyzed with $0.3 \mathrm{mg} \cdot \mathrm{kg}^{-1}$ of d-tubocurarine. The lambs were intubated and mechanically ventilated. Tidal volume was set at approximately $10 \mathrm{ml} \cdot \mathrm{kg}^{-1}$ and the respiratory rate adjusted to maintain a $\mathrm{PaCO}_{2}$ of $40 \pm 5 \mathrm{mmHg}$. An overhead radiant warmer and a Thermistemp Temperature Controller (Yellow Springs Instrument Co. Yellow Spring, Ohio) maintained their body temperature constant. Hydration was maintained by administering $4 \mathrm{ml} \cdot \mathrm{kg}^{-1} \cdot \mathrm{hr}^{-1}$ of normal saline intravenously.

One groin and the neck were anaesthetized with one per cent lidocaine before inserting catheters into a femoral artery and vein and into a lingual artery. The tip of the lingual artery catheter rested at the junction of the lingual and carotid artery without 
protruding into or obstructing the carotid artery. All extracranial branches of the carotid artery were visualized and ligated to prevent loss of xenon to extracranial vessels during the measurement of cerebral blood flow. One per cent lidocaine was injected into the skin and muscle overlying the parietal bone on the same side as the catheter in the lingual artery. A $1 \mathrm{~cm}$ diameter burr hole was created in the parietal bone and a $5 \mathrm{~mm}$ diameter lead collimated, thallium activated $\mathrm{Nal}$ detector was placed over the exposed dura.

The detector was connected to a Medimatic ratemeter (Medimatic, Irvine, CA). Cerebral blood flow was measured by the xenon washout technique. ${ }^{1,6}$ Briefly, we dissolved $0.5 \mathrm{mCi}$ of 133 xenon in $1 \mathrm{ml}$ of normal saline, injected it into the lingual artery catheter, and flushed the catheter with $1 \mathrm{ml}$ of normal saline. Both injections were completed in less than 15 seconds. Each xenon washout curve was inscribed on paper by a Hewlett Packard $X-Y$ plotter (Hewlett Packard, Brisbane, CA) and cerebral blood flow was calculated by the initial slope method. ${ }^{7}$

Arterial blood gases and $\mathrm{pH}$ were measured with a Coming 165 blood gas apparatus (Coming Medical, Medfield, MA) and corrected for body temperature. We continuously monitored arterial blood pressure with a Statham P23 transducer connected to a Grass Polygraph recorder (Grass Instrument Co, Quincy, MA).

Autoregulation of cerebral blood flow was assessed by measuring cerebral blood flow at normal, resting mean arterial blood pressure (MABP) and again 2 min after elevating the mean arterial blood pressure 30 per cent with a constant infusion of 0.02 per cent phenylephrine hydrochloride. Autoregulation was considered impaired if cerebral blood flow increased significantly when we increased the arterial blood pressure.

The animals were randomly assigned to two groups. Group I were control subjects; Group II were study subjects. All animals were allowed to recover from surgery for 2-3 hours, at which time they were normoxic $\left(\mathrm{PaO}_{2}>60 \mathrm{mmHg}\right)$, normocapnic $\left(\mathrm{PaCO}_{2} 35-45 \mathrm{mmHg}\right)$, and had normal cerebral vascular autoregulation present. Group II animals received $10 \mathrm{mg} \cdot \mathrm{kg}^{-1}$ of lactic acid BP by intravenous infusion over 30 minutes. Group I animals received an equal amount of normal saline over the same time period.

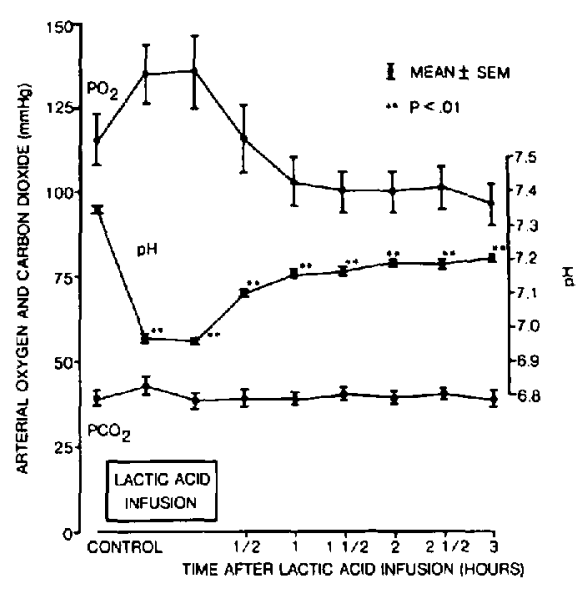

FIGURE 1 Arterial blood gas values for lambs who received lactic acid infusion.

After the infusion of acid or saline, cerebral blood flow, cerebral vascular autoregulation, arterial blood gases, arterial blood pressure and heart rate were determined at 30 minute intervals for 180 minutes. The data were analyzed for statistical significance by two-way analysis of variance and Duncan's Test for multiple comparisons. A p value of 0.05 or less was considered significant.

\section{Results}

The arterial blood gases and haemodynamic parameters are shown in Figures 1 and 2.

Arterial blood pH of Group II (lactic acid) lambs decreased from $7.35 \pm 0.01$ (mean \pm SEM) before lactic acid infusion to $6.96 \pm 0.02$ at the end of lactic acid infusion. One hour later, the mean $\mathrm{pH}$ recovered to $7.16 \pm 0.01$ and remained at this level until the end of the study. The $\mathrm{PaCO}_{2}$ was between 38 to $40 \mathrm{mmHg}$ throughout the study. The $\mathrm{PaO}_{2}$ was 96 to $116 \mathrm{mmHg}$ before and after lactic acid infusion. The $\mathrm{PaO}_{2}$ rose insignificantly to $135 \pm$ $29 \mathrm{mmHg}$ during lactic acid infusion. Group I (control) lambs had arterial pH of $7.30 \pm 0.03$ to $7.33 \pm 0.01, \mathrm{PaCO}_{2}$ of 39 to $42 \mathrm{mmHg}$ and $\mathrm{PaO}_{2}$ of 98 to $109 \mathrm{mmHg}$ during the study periods.

The resting mean arterial blood pressure (MABP) was between 70 and $80 \mathrm{mmHg}$ and the heart rate 187 to 210 beats per minute throughout the study in Group II (lactic acid) lambs. The slight rise in heart rate during lactic acid infusion was not statistically 


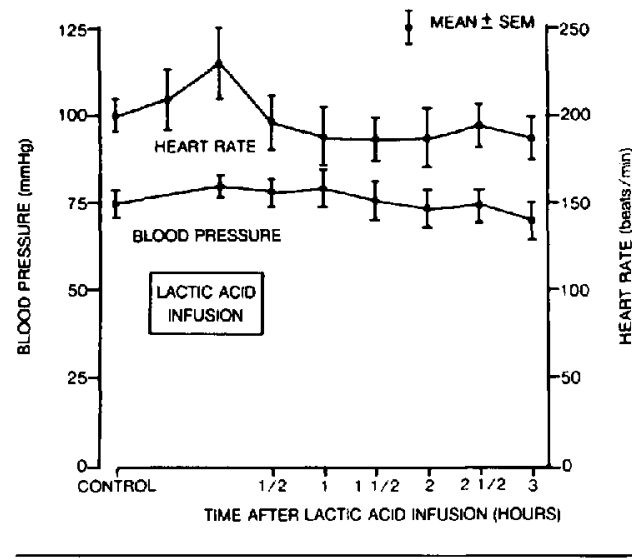

FIGURE 2 Heart rates and blood pressures of lambs who received lactic acid infusion.

significant. Group I lambs had mean arterial blood pressure of 77 to $88 \mathrm{mmHg}$ and heart rates of 216 to 233 beats per minute.

Figure 3 shows the cerebral blood flow (CBF) at resting mean arterial pressure for Group II. Before lactic acid infusion, CBF was $53 \pm 3 \mathrm{ml} / 100 \mathrm{~g} / \mathrm{min}$. After lactic acid infusion, CBF was 52 to $55 \mathrm{ml}$ $100 \mathrm{~g} / \mathrm{min}$. The cerebral blood flows of the Group I (control) animals were $56-58 \mathrm{ml} / 100 \mathrm{~g} / \mathrm{min}$ and showed no significant change over the same periods of time.

As the CBF values did not change over time, the CBF's after lactic acid or saline infusions were combined into study and control groups respectively for presentation.

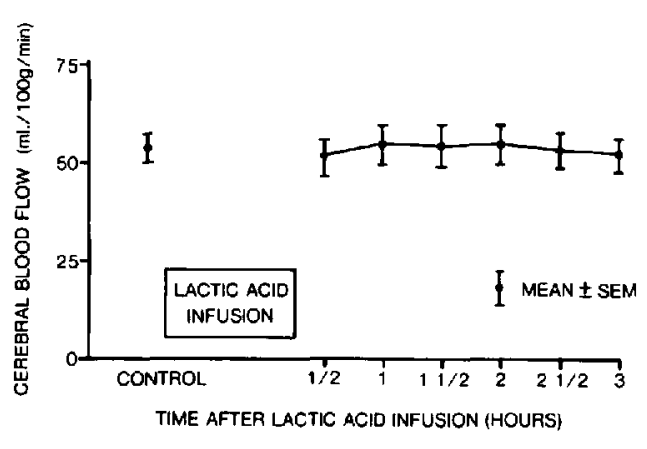

FIGURE 3 Cerebral blood flows at resting blood pressure for lambs who received lactic acid infusion.

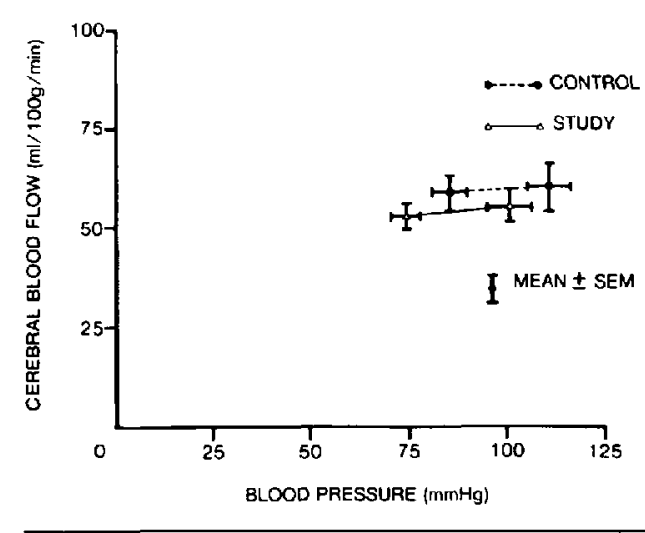

FIGURE 4 Cerebral blood flows at resting and elevated mean arterial pressure for Group I (control) and Group II (study) lambs prior to saline or lastic acid infusions.

Figures 4 and 5 present the data from the autoregulation studies. In Group II lambs, CBF was $53 \pm 3 \mathrm{ml} / 100 \mathrm{~g} / \mathrm{min}$ at resting MABP and $56 \pm$ $4 \mathrm{ml} / 100 \mathrm{~g} / \mathrm{min}$ at elevated blood pressures before the lactic acid infusion. The corresponding flows for the control animals were $58 \pm 5$ and $60 \pm$ $6 \mathrm{ml} / 100 \mathrm{~g} / \mathrm{min}$. The maintenance of steady cerebral blood flow after blood pressure elevation indicated autoregulation was present in both groups of animals when their pH's were normal.

After lactic acid infusion, CBF of Group II lambs increased significantly from $54 \pm 2$ to $62 \pm$

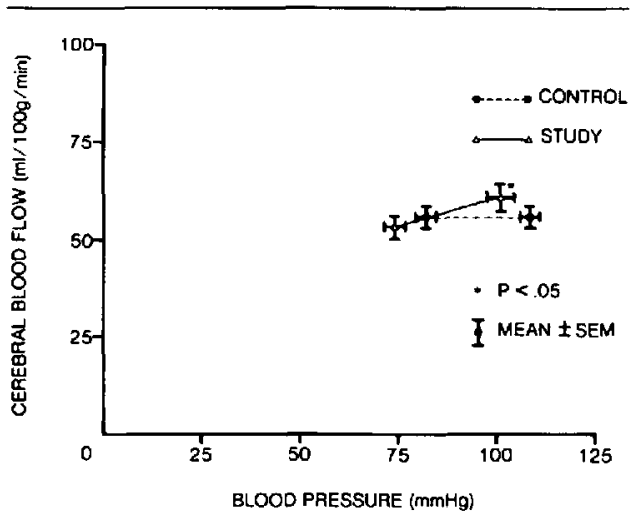

FIGURE 5 Cerebral blood flows at resting and elevated mean arterial pressure for Group I (control) and Group II (study) lambs after saline or lactic acid infusions. 
$3 \mathrm{ml} / 100 \mathrm{~g} / \mathrm{min}$ when MABP was elevated. Control animals (Group I) maintained their mean cerebral blood flows within $1 \mathrm{ml} / 100 \mathrm{~g} / \mathrm{min}$ of their resting level ( $56 \pm 3$ to $57 \pm 3 \mathrm{ml} / 100 \mathrm{~g} / \mathrm{min}$ ) after blood pressure elevation. The significant change in CBF with increased MABP indicated impaired autoregulation after lactic acid infusion.

\section{Discussion}

After lactic acid infusion, the lambs partially compensated for their metabolic acidosis. Their arterial $\mathrm{pH}$ recovered relatively quickly to between 7.10 and 7.20 where it remained for the rest of the study. This suggests the newborn lambs have limited ability to buffer, excrete or metabolize lactic acid. Respiratory compensation did not occur because we controlled ventilation throughout the study.

The heart rate response of the lambs in this study to acidosis was consistent with that reported previously in foetal lambs. Vaughn et al. ${ }^{8}$ and Mann $e t$ $a l^{2}$ both reported insignificant heart rate changes with metabolic acidemia, which probably reflects an interaction between an active sympathetic nervous response and direct metabolic depression in response to metabolic acidemia. In isolated foetal heart preparations, metabolic acidemia reduces heart rate. Blood pressure was also stable in the lambs during acidemia, suggesting an adequate compensation for the direct vasodilation effects of increasing hydrogen ion concentrations.

The slight rise in $\mathrm{PaO}_{2}$ during lactic acid infusion was probably caused by a rightward shift in the oxyhaemoglobin dissociation curve with metabolic acidemia. The reduced oxygen affinity would produce a higher partial pressure of oxygen at the same oxygen sturation.

We did not observe a change in cerebral blood flow with metabolic acidemia by itself. This finding is in agreement with that of Mann et al. ${ }^{2}$ who saw no significant change in carotid blood flow when they infused lactic acid into foetal lambs. Bucciarellia and Eitzman ${ }^{3}$ reported a direct correlation between cerebral blood flow and arterial hydrogen ion concentrations in neonatal goats. The disparity between these results might be due to differences in animal species or to the time of cerebral blood flow measurements. In this study, there was a 30-minute period of stabilization between the end of lactic acid infusion and the first set of measurements. Bucciarelli and Eitzman made no mention of a stabilization period between the infusion of acid and measurement of cerebral blood flow. In addition, many of their goats had previously been used for hypoxemia studies. Residual effects of hypoxia (loss of cerebral vascular autoregulation) might have altered the findings. In adult dogs, Harper and Bell showed that metabolic acidemia had no effect on cerebral blood flow. ${ }^{9}$

The control group (Group I) demonstrated autoregulation of their cerebral blood flow. This agrees with the findings of Purves and James ${ }^{1}$ who reported stable CBF in neonatal lambs with mean arterial blood pressures of $45-90 \mathrm{mmHg}$. Our data suggest that autoregulation is present up to mean blood pressures of $111 \mathrm{mmHg}$, which is 30 per cent above the resting blood pressure.

Elevation of mean arterial blood pressure with phenylephrine increased cerebral blood flow in the acidemic lambs but not in the control lambs, indicating that metabolic acidemia impaired autoregulation of cerebral blood flow. If this occurs in human neonates, loss of autoregulation in the perinatal period might leave the immature brain vulnerable to changes in systemic blood pressure. Hypertension may increase cerebral blood flow and expose the fragile vessels of the germinal matrix and brain stem to high pressures, which may lead to intracranial haemorrhages. While hypotension was not studied, there is a strong possibility that hypotension might decrease blood flow to the brain, and cause cerebral ischaemia.

In conclusion, cerebral blood flow autoregulation is present in healthy newborn lambs. It is impaired by persistent metabolic acidemia. Therefore, acidemic neonates should probably have their $\mathrm{pH}$ corrected and their systemic blood pressures maintained at normal levels to prevent excessive fluctuations in cerebral perfusion.

\section{References}

1 Purves MJ, James IM. Observations on the control of cerebral blood flow in the sheep fetus and newbom lamb. Circ Res 1969; 25: 651-67.

2 Mann LI, Solomon G, Carmichael A, Duchin S. The effect of metabolic acidosis of fetal brain function and metabolism. Am J Obstet Gynecol $1971 ; 111: 353-5$. 
3 Bucciarelli RL, Eitzman DV. Cerebral blood flow during acidosis in perinatal goats. Pediat Res 1979; 13: 178-80.

4 Wigglesworth JS, Pape KE. An integrated model for haemorrhagic ischemic lesions in the newborn brain. Early Hum Dev 1978; 2: 179-91.

5 Lou HC, Lassen NA, Friis-Hansen B. Impaired autoregulation of cerebral blood flow in the distressed newborn infant. J Pediatr 1979; 94: 119-21.

6 Lassen NA, Ingvar DH. Radioisotopic assessment of regional cerebral blood flow. Pros Nucl Med 1972; 1: 376-409.

7 Olesen J, Paulson OB, Lassen NA. Regional cerebral blood flow in man determined by the initial slope of the clearance of intra-arterially injected 133 Xe. Stroke 1971; 2: 519-40.

8 Vaughn D, Kirschbaum TH, Bersentes $T$, Dilts $P V$ $J r$, Assali NS. Fetal and neonatal response to acid loading in the sheep. J Appl Physiol 1968; 24: 135-41.

9 Harper AM, Bell RA. The effect of metabolic acidosis and alkalosis on the blood flow through the cerebral cortex. J Neurol Neurosurg Psychiatr 1963; 26: $340-4$.

\section{Résumé}

Le flot sanguin cérébral ( $C B F$ ) et son autorégularisation ont été évalués chez des agnelets avant et après induction d'une acidémie métabolique. Le flot sanguin cérébral a été mesuré par la méthode de lavage au xénon et l'autorégulation par le changement du flot sanguin cérébral suite d̀ l'augmentation de 30 pour cent de la pression artérielle moyenne (MAP) avec 0.02 pour cent de phényléphrine. Après la préparation chirurgicale, la stabilisation, et la mise en évidence de l'autorégulation, six agnelets ont reçu $10 \mathrm{mg} \cdot \mathrm{kg}^{-1} \mathrm{~d}^{\prime}$ acide lactique par voie intra-veineuse pour une période de 30 minutes. Leur $\mathrm{pH}$ artériel a diminué de $7.35 \pm 0.01$ (moyenne \pm SEM) pour la période de contrôle à $6.96 \pm 0.02(p<0.01)$ d la fin de la perfusion de l'acide lactique. Les gaz artériels sanguins, la pression artérielle moyenne et la fréquence cardiaque n'ont pas changés. Avant la perfusion d'acid lactique le flot sanguin cérébral qui était de $53 \pm$ $3 \mathrm{mll} / 00 \mathrm{~g} / \mathrm{min}$ avant l'augmentation de la pression artérielle moyenne, monta à $56 \pm 4 \mathrm{ml} / 100 \mathrm{~g} / \mathrm{min}$ après. Après le perfusion d'acide lactique le flot sanguin cérébral augmenta de $54 \pm 2 \mathrm{ml} / 100 \mathrm{~g} / \mathrm{min}$ à $62 \pm$ $3 \mathrm{ml} / 100 \mathrm{~g} / \mathrm{min}(p<0.05)$ suite da l'augmentation de la pression artérielle moyenne induite par la phényléphrine. Cinq agnelets de contrôle n' ont pas démontré de changements significatifs dans aucune de ces variables incluant le flot sanguin cérébral et ce pour la même période. Ces données indiquent que l'acidose métabolique en tant que tel n'altére pas le flot sanguin cérébral. Cependant l'acidose métabolique altère l' autorégulation vasculaire cérébral chez les agnelets hyper-oxiques. Des changements identiques chez les nouveaux-nés peuvent provoquer une hémorragie intracrânienne. 